\title{
The Character of the Principles of Criminal Law and Criminal Responsibility: Between the Philosophy of Law and Semiotic
}

\section{Michał Peno ${ }^{1}$ (1)}

Published online: 9 August 2019

(C) The Author(s) 2019

\begin{abstract}
The article has three basic goals. The first one is to characterize the so-called the principles of criminal liability (or, in other words, the rules of criminal law) as especially significant legal norms (that can be characterized from semiotic point of view), but also certain patterns of determining (the system of) criminal law. The second goal is to characterize the rules as patterns or guidelines, which are a kind of rules constructing the system of criminal law. These rules are also briefly defined from a semiotic perspective. The last part of this article concerns the possible philosophical and political types of determining criminal liability and aims at concluding general theoretical reflections. The article deals primarily with the semiotic and philosophical character of special rules (the so called principles) constructing the criminal law system.
\end{abstract}

Keywords Directives - Legal principles · Criminal law · Models of justice system · Rules for constructing legal system

\section{Introduction}

The article has three basic goals. The first is to define the so-called principles of criminal responsibility (or, in other words, the rules of criminal law), ${ }^{1}$ as they are particularly significant legal norms, and also certain patterns of determining (the

\footnotetext{
${ }^{1}$ At the core of defining criminal law is criminal responsibility and the manner of its identification (essentially included in the so-called general part of criminal laws). Therefore, the rules of criminal law and criminal responsibility will be treated equally. The terms " responsibility" or " outcome responsibility" are used similarly to the quoted meaning in English by H. L. A. Hart in Punishment and Responsibility: Essays in the Philosophy of Law published first in Oxford in 1968.
}

\section{Michał Peno}

m.p.peno@gmail.com; michal.peno@usz.edu.pl

1 Faculty of Law and Administration, University of Szczecin (Poland), Gabriela Narutowicza 17A, 70-240 Szczecin, Polska 
system of) criminal law. The second goal is to characterise the rules as patterns or guidelines, which are a type of rules making up the system of criminal law. The use of the term "rule" is analogous to "directive", as used by Alf Ross. ${ }^{2}$ In this sense, the term "rule" is broader and covers different types of directives, i.e. normative principles, norms, teleological rules and rules in the conventional, cultural sense, as will be shown below. These rules are also briefly defined from a semiotic perspective. By way of conclusion, the final part of this article concerns the possible philosophical and political iterations of criminal responsibility determinations, offering directions for future research. The main purpose of this article is to present problems and not provide solutions, as that would require a different, wider approach. ${ }^{3}$

In European legal culture, a specific concept of criminal responsibility has developed. ${ }^{4}$ It includes the conditions for imposing criminal sanctions, and defines the concept and structure of a crime. Thus, sometimes the term "principle" is used in relation to the condition of criminal responsibility. There is, for example, the principle of guilt. ${ }^{5}$ In this context, Latin terminology is also used very often, such as nullum crimen sine culpae, nullum crimen sine periculo sociali etc. It seems, however, that the word "principle" has more than one meaning. Therefore, the aim of the first part of this article is to perform a semiotic characterisation of the principles.

The word "principle" can be misleading. Usually, it is understood as a special rule (directive). ${ }^{6}$ These principles, however, are not necessarily considered as rules. They do not have to be read normatively. They can be models, describing legal structures or institutions (legal institutions can be understood as a sets of rules regulating particular sections of social life, e.g. marriage). Principles, in that sense, would describe the essence of these institutions. ${ }^{7}$ The principles of criminal responsibility can consequently be treated as patterns forming criminal law. As such, they describe the model system of criminal responsibility and its particular elements. Criminal responsibility will be described from the point where the committed crime incurs a punishment, provided that such act was culpable and regulated by penal law (i.e. nullum crimen sine lege certa, nulla poena sine lege poenali anteriori) etc. Such models of determining criminal responsibility (and criminal law per se) can be referred to in at least two ways. First of all, they can be used in the law-making process as models for the creation of criminal law institutions. They can also be used as patterns by those entities (legislator, legal doctrine-jurisprudence), who want to establish a new penal code in a particular country or form a "universal" criminal law at the European (or international) level. Secondly, they can serve as criteria for evaluating existing standards, sets of norms or criminal law institutions (the lex lata criterion). If a certain pattern is adopted as the ideal criminal responsibility, for example social defence or retributive justice, being models formulated by legal

\footnotetext{
2 Ross (1968: 34ff., 78).

3 This approach requires a monograph-length enquiry.

4 Merryman (1969: 132).

5 Bohlander (2009: 18-21).

6 e.g. Alexy (2000: 294-304), Dworkin (1969: 14ff).

7 Wronkowska et al. (1987: 179-188), Peno and Jaskiewicz (2018: 21-33).
} 
doctrine (i.e. legal science), it can certainly serve as a criterion for the evaluation of the current criminal law system. It seems, however, that the principles of criminal responsibility function mainly as rules (norms), so consequently they determine obligations. Unlike the descriptive approach, this is a typical way of viewing principles in the field of legal philosophy.

Norms that can be distinguished from other rules by their significance (for legal scholars, jurisprudence, legal culture etc.), and known as principles of law, can be analysed on three different levels: first, as principles describing basic rights and obligations in the current criminal law system (lege lata level); secondly, as obligations defining the structure, shape or content of the criminal law system per se (a meta level of the legal system, the level of "Grundnormen", this level is an aggregation of principles that determine a legal system understood as a set of norms enacted by the legislator). As such, they can denote obligations connected to the way the criminal law system is shaped. In that context, however, it seems that the principles of criminal responsibility do not actually have to be identified with strict norms or rules of conduct. They can establish the obligation (by the legislator) to accept these patterns of shaping the system of criminal responsibility and not others. This is the third level of analysis of the sets of rules of criminal law, namely viewing them as meta-principles (meta-rules), due to their reference to the creation of law not in the formal but in the content aspect. These principles can be referred to as the rules for constructing a system of criminal responsibility. By omitting the word "principle", we can simply talk about the rules of criminal responsibility. These rules are not consistent in nature, but they do share a fundamental structure.

It should be stressed that the rules for the construction of a legal system that determine the manner criminal law is shaped, show some similarities to the principles of law as presented in Ronald Dworkin's approach, except for the fact that they are applied primarily to the creation of law and, only as a consequence, to the application and interpretation of law. ${ }^{8}$ These principles also show fundamental values. The application and interpretation of law take into account the values coded in the legal text by the legislator during the law-making process, but originally the legislator has to use values encoded in the principles for the construction of a legal system as long as the given set of principles belongs to a valid normative frame (validation depends on the ideological, political or social system etc.).

\section{Types of Rules for Defining Criminal Responsibility}

At this point, the nature of the rules (principles) forming the criminal law system should be specified. There are three types of rules (directives) that have deontic meaning. According to von Wright, ${ }^{9}$ one can adopt a typology of rules (directives), such as: norms of conduct (e.g. legal norms—-strong commands), technical

\footnotetext{
8 Dworkin (1980: 22ff).

9 von Wright (1963: 6-17).
} 
directives (teleological directives) and the so-called rules of sense. ${ }^{10}$ The first type expresses order or prohibition, the second indicates the means to achieve the desired conditions, while the third shows how important it is to perform certain conventional acts (for example, establish a criminal bill). ${ }^{11}$

Rules defining (constructing) the principles of criminal responsibility can be described in three ways: as strict norms, technical directives and as the so-called rules for the valid performance of conventional activities (acts). These rules can be treated as firm standards addressed to the legislator, ordering or prohibiting the creation of institutions or responsibility rules in a specific way. Whether these norms are considered autonomous is a matter connected to legal philosophy on the assumptions and the way of understanding law. The value of autonomy is recognised by the legislator themselves (as in the case of classical legal positivism) or originates from righteousness, morality or tradition (from the perspective of natural law tradition).

These rules will enforce the adoption of such and no other models and establish criminal law based on these models (describing the way criminal responsibility is defined). This is why these rules are binding until the adoption of certain legislative solutions. Traces of these obligations can be seen in the law itself. It can be the case, for example, that the constitution provides for the principle of guilt (nullum crimen sine culpae) or social danger (nullum crimen sine periculo sociali) as an act of criminal responsibility. Then, the origin of the obligation to adopt particular legislative solutions is clear. ${ }^{12}$ The content of the constitution is usually the result of a decision reinforced under certain social consensus; in this way, the legislator is bound by the power of particular meta-rules (rules regarding the regulations of the legal system) ordering the public sphere, including criminal responsibility. ${ }^{13}$

Such meta-rules may be connected with the value of the rule of law, a particular philosophical tradition, law or ideology. Thus, following the October Revolution, the communist government took on the principle of no guilt connecting regular crimes with the bourgeois and social injustice, while enforcing a law punishing dangerous acts from the perspective of revolutionary awareness etc. ${ }^{14}$ When it comes to the second approach, the system rules serve as purposeful directives. If we presume that the legislator wants to establish effective laws that suit certain requirements of correctness, equity and instrumental effectiveness, then they should follow one of the technical directives.

The rules of criminal responsibility can be treated as directives indicating how to proceed in order to create a set of rules matching the intentions of legislators, philosophers and politicians. The legislator can adopt those rules as they did with the achievements of representatives of the humanitarian reform stream during the Enlightenment, or by referring to various models or criminal regulations established in legal doctrine. In the final approach, the rules of constructing criminal law,

\footnotetext{
10 Woleński (1999a: 201-215).

11 cf. Woleński (1999b: 181-200), Czepita (1994: 31-38).

12 cf. Bilionis (1998: 1269-1334), Dubber (2004: 509-572).

13 Shapiro (2003: 109-150), Scalia (1989: 1175-1188), Dubber (2005: 1-38).

14 Starosolsky (1950: 359-374), Los (1988: 249-291).
} 
including the rules of criminal responsibility, can be treated as the rules of validity of complex conventional activity (aggregation of activities) which include the formation or creation of new laws, establishing normative acts (which may be either valid or invalid, depending on their compliance with binding rules of law-making, such as the passing of bills).

In this last case, it is interesting that we are able to imagine a vision of criminal law, which due to punitive and repressive criminal punishment requires particular conditions, such as special majority, in order to pass new rules of responsibility or change existing ones (the problem of the recognition of the legal system can be omitted here, and it can be treated as a set of norms, regulations or normative $\left.\operatorname{acts}^{15}\right) .{ }^{16}$ Such rules as lex retro non agit, lex posteriori derogat legi priori may be important for criminal law and criminal responsibility. ${ }^{17}$

It can be argued that from the perspective of the principles of criminal responsibility (criminal law principles), it is essential to examine the inclusion of norms requiring the adoption of specific decisions by the legislator concerning the creation of criminal law. They mainly concern obligations or prohibitions from the state itself (thus, the decisions of the legislator and the sovereigns are autonomous, because they are addressed to the creator themselves, just like the rules describing the content of contracts underwritten in private or public international law). These contracts can be prima facie altered, repealed, cancelled or supplemented at any time. They would also require the adoption of technical directives that involve strictly defined measures in order to implement the goals set by the legislator.

In this way, they would set the direction of legal policy. The general goal would be to fight crime very broadly defined. To put it more precisely, the norms that require the application of technical directives would have to be based on specific knowledge, especially concerning fighting crime (criminological, sociological, psychological etc.).

Therefore, criminal policy must assume that the legislator has this particular knowledge, which means that they are rational and can be held accountable. This is the model (idealisational) of a rational legislator. The legislator's rationality concerns both technical knowledge (on the causes of crime and fighting it) and axiological attitudes (their value system). Such rationality can be attributed to a jurisprudential or conventional legislator (an entity with legislative competence), who is a product (model) of a particular convention adopted by lawyers. ${ }^{18}$ It is not necessarily attributed to the sociological or factual legislator (legislator de facto, i.e. officials, politicians and other persons who create or are involved in the creation of law in a form of legal texts), because they often follow political interest or crude emotions, which have no bearing on rationality or instrumental rationality.

\footnotetext{
15 Apart from the rules of valid law-making, there are additional rules concerning the valid creation of criminal laws.

16 Husak (2008: 35, 122-156), Gainer (1998: 74).

17 Fuller (1969).

18 Peczenik (2005: 75-105), Feteris (1999: 62-72).
} 
Creating a rational model of legislator (echoing Jeremy Bentham or, in Polish theory of law, Leszek Nowak's so-called humanistic interpretation) makes practical sense, because it can be used to assess legislative activities. ${ }^{19}$ What is more, such an ideal rational legislator should be a role model for legislators and policy makers. They should try to achieve perfection in their field and set a precedent, similar to a person who is proclaimed a Christian saint (we must strive for perfection also in our moral political obligations, adhering to the ethos of the Greek polis).

\section{The Principle of Responsibility as the Key Principle of Criminal Law}

The assumption of responsibility has a basic premise: nullum crimen sine poena. ${ }^{20}$ This assumption has an ontological (claiming that man is responsible for the acts they have committed, because responsibility is possible in our world) and normative character, according to which a man (as a human being) ${ }^{21}$ should take responsibility for their (own) actions. There are two possible scenarios that arise: enforcing the assumption of responsibility or mercy and absolution. The second scenario concerns ideologies (usually utopian, for example Christianity), ${ }^{22}$ and can be assigned to corrupted and dysfunctional governments, though not exclusively. ${ }^{23}$ Nazis, for instance, connived crimes against mentally handicapped people, communists or Jews. Deliberate crimes for ideological reasons are popular even nowadays.

In other words, the legislator, in order to implement the principle of responsibility, must follow the rule that a person should try to reduce undesirable social phenomena (crimes), and not to neglect or support them (even partially).

It was mentioned above that the rules for shaping the criminal law system and responsibility can include technical directives that assume that their respondent wants to achieve the particular goal set by them. Is the legislator, however, obligated to achieve the goal of limiting (fighting) crime? It seems that in the state of law, this should result from the values and rules of almost all human rights systems (in Europe, they derive from the dignity of human beings). The principle of responsibility assumes that the legislator is obligated to achieve this goal. The legislator, therefore, is legally obligated to pursue this goal set by the technical directive on fighting crime. It can be understood that responsibility can be recognised as a principle, setting a pattern for determining a legal system per se, but also introducing a way of regulating social relations, making the following two assumptions:

1) that the recipient of the standard is motivated to introduce it;

2) being held accountable for its violation. ${ }^{24}$

19 Bentham (1817), Nowak (1987: 137-147), Harsanyi (1982), Selznick (1994: 39-62).

20 Dubber (2005: 2-37), Lucas (2004: 124-140).

21 Or another subject with moral attributes.

22 e.g. Arians, protesters in the sixteenth-seventeenth centuries, extremely pacifist.

23 Lucas (2004: 204-220).

24 cf. Duff (2007). 
The problem is that these rules regarding criminal responsibility are not put into effect or even correctly put together (as mentioned previously, they should not be mistaken with the rules of responsibility found in penal law). In penal law, it is possible to recreate rules, at least partially, quasi-inductively, from fragments of criminal laws. Due to the fact, however, that the rules of criminal responsibility (lex lata) are determined in a certain way, it cannot be assumed that they should be in such a shape (de lege ferenda). They may be formed incorrectly, from a particular point of view. More important, however, is the question of the role and authority that should be given to these rules for the construction of criminal responsibility (rules for shaping the principles of criminal responsibility). It seems that they ought to be formulated clearly and attached systematically to a specific legal act concerning the rules of criminal law and criminal responsibility.

Nevertheless, they constitute in some way meta-criminal law (meta-rules), higher level regulations, compared to criminal law, and in this way they are closer or analogous to constitutional rules (they are, however, different to the established or recognised norms of the constitution), but not quite, as they would have to be much more elaborate and precise, referring to only one branch of law and aspect of social life. Perhaps they can help break the impasse of common mistakes in defining a crime (e.g. a crime is an act prohibited under penalty by a penal act).

It should be added here that in their basic and general form, these rules (metarules) of criminal law (principles-rules of constructing the criminal law system) are not a source of law in the strict, positivist sense. ${ }^{25}$ They are more akin to intuitive rules that refer to the multitude of the so-called soft sources (including recommendations from psychology, sociology or ethics, like the principle of guilt).

\section{Types of Criminal Law Systems}

There are different types of criminal law systems, which do not depend on decisions regarding the (possible) semiotic status of the directives (rules) of criminal responsibility. The distinction between these types of criminal responsibility can refer to the methods of rationalising punishment (this criterion can be described as criminological). ${ }^{26}$ Using some simplifications for technical reasons, we can indicate, for example, a model of retributive responsibility, where criminal responsibility equals to moral responsibility for a deliberate (culpable) external act (or omission) prohibited under the threat of so-called criminal punishment, by the law binding at the time of its occurrence. ${ }^{27}$

The penalty will mainly serve as payment. A model of criminal responsibility referring to the social threat posed by the perpetrator, however, will be different. A

\footnotetext{
25 cf. Czepita (1994: 31-38).

26 The analyzed models are only the result of general arrangements requiring a deepening. They do not have strong empirical foundations, but nevertheless they have a certain cognitive and practical value, from the philosophical point of view.

27 Zaibert (2006: 81-118), Primoratz (1989: 187-205), Cane (2002: 1-28), Feinberg (1970: 97).
} 
punishment will aim at protecting the healthy core of society and rehabilitating the culprit. The corrective justice model will focus on a consensual resolution of the conflict, especially by repairing the damage caused by the offence. This is possible only if an evil caused by the crime can be repaired (Latin knows the concept of evil, which is reparabilis, unlike the one that can not be repaired). ${ }^{28}$

Depending on the type that we adopt, the legal provisions of the general part of the penal code will be formed differently, in terms of defining the crime (rules and conditions of responsibility, definition of crime, guilt, exclusion of responsibility), as well as the types of applicable penalties (parole measures or instruments of corrective justice, for example, double-track codes based on the ideas of the sociological school of penal law, which include the means of criminal reaction, which should not take place under conditions of classical retributivism etc. See: Tunick (1992: 69 ff.), Bennett (2002: 145-163), Tebbit (2005: 155-230).). It is worth mentioning that the adopted pattern will define the direction of criminal policy.

Another criterion may be related to political philosophy, including the current state of justice or the legitimacy of the legal system. This criterion is very unclear and, what is more, the chosen type is not the result of a conscious decision. In fact, the description of a system will form the ground for establishing the postulates or rules shaping criminal responsibility. This criterion is political. ${ }^{29}$

Generally speaking, criminal responsibility (in every sense of the word) can be understood in a specific normative order (von Wright (1985: 263-280)). In pre-states or nature states, categories such as responsibility simply did not exist, as Thomas Hobbes explained. ${ }^{30}$ Moreover, according to Jürgen Habermas, we can draw the conclusion that law (positive law) in contemporary times has become an institution that shapes responsibility, including responsibility for the functioning of structures and social institutions. ${ }^{31}$

When it comes to social consciousness, the law itself has become responsible for the state of social relations - setting and defining the relations between people as an external force. It also maintains general order and triggers necessary changes. We could formulate a statement claiming that without law there is no criminal responsibility. This also reveals the community and cooperative aspect of responsibility, because, although some people take their own responsibility, this only happens in a social value system, where they have to co-exist and cooperate with others. ${ }^{32}$

Some normative systems are similar in terms of regulating criminal responsibility and, therefore, we can distinguish certain types of principles (patterns) of responsibility in law. This is not only about the traditional dispute over determinism and free will, or the place of man in society or that of the legislator and law enforcement authorities, but about a comprehensive way of regulating responsibility and its

\footnotetext{
28 Cragg (2016: 12).

${ }^{29}$ Ristroph (2016: 76-92).

${ }^{30}$ Carvalho (2017: 249-271), Branstetter (2017: 778-789), Bobbio (1993: 66-67).

31 Habermas (1987: 270ff).

32 Ripstein (1999: 12-19), Selznick (1994: 319-356).
} 
rules. ${ }^{33}$ In other words, different ways of determining criminal responsibility could be distinguished.

The way to determine responsibility in law reflects some ideological and philosophical assumptions, which are the foundation of the legal system. Of course, at the normative level, the regulations concerning the terms and the subject of responsibility are at the forefront. Analyzing the criminal law systems that emerged in Western jurisprudence, certain types of criminal law can be distinguished. They form patterns or models (of legal institutions). Depending on the semiotic character attributed to these models, they will play different roles in the philosophy of law and in theoretical inquiries. For example, considering them as "hard norms", the legislator will be required to adopt such or other legislative solutions. They may also be considered as ideals to which the existing systems will be approaching (e.g. wanting to achieve given social, moral or political goals). There may be different typologies. In this article, three models are assumed (somewhat arbitrarily) as basic ones. It seems that there are three types of responsibility in the law: (a) the liberal type; (b) the social-liberal type; and (c) the totalitarian type. ${ }^{34}$ It is also worth mentioning the quasi-democratic (anti-liberal and socially conservative) type characterising, for example, Polish criminal law (and criminal systems in other Central European regions, like Hungary). This will be categorised as type (d).

The characteristics of the above-mentioned types can be reduced to indicate the basic principles of responsibility. It should also be noted that the remarks concern primarily the paradigmatic responsibility in law-criminal law. They could also refer to the typology of other branches of law.

(a) Liberal type. This type is characterised by a retrospective justification of responsibility, based on Kant's ethics. ${ }^{35}$ It is the institution that serves a punishment proportionate to the crime. The terms of responsibility in this particular type are determined by the principle of guilt - the responsibility is therefore programmatically relative. The extent and subject of responsibility are limited by the so-called principle of damage. When it comes to the limits of responsibility (exclusion of responsibility), generally the non-guilty subjects are not held responsible. It is also forbidden to isolate people in the curative mode; the consequences of responsibility are unarguably proportional to the extent of the subject of responsibility. We should also accept the formal equality of every subject violating legal norms. Models of such type accept the necessary defence, the state of higher necessity, which denotes a justification consistent with parochial morality. ${ }^{36}$ The philosophical approach represented in this type is anthropologi-

\footnotetext{
33 Vilhauer (2013: 143-163), Pereboom (2003).

34 cf. Kymlicka (2001).

35 Lucas, discussing the liberal type from the philosophical and political point of view on punishment, points out the connection between liberalism and retributivism (Lucas 2004: 282-284; cf. Johnson 1969). 36 Honderich (2005: 36ff.), Anderson (2010: 1-31), Nozick (1981: 377-392), Ryberg (2004: 43-50).
} 
cal indeterminism. ${ }^{37}$ The liberal type of responsibility is an ideal model in the study of criminal law, characteristic, for example, of neoclassicism, while in the philosophical and political arena it is a type especially close to liberal/conservative views. This type is very common for the various incarnations of "law as a constitution for freedom". 38

(b) Social-liberal type. In this type, responsibility has utilitarian (consequentialist) justification and is included in mechanisms of prevention and resocialisation. ${ }^{39}$ The conditions of responsibility are governed by the principle of social harm (social danger), as a primary condition of responsibility, and (as a rule with exceptions) the principle of guilt. The range and subject of responsibility are determined by the principle of damage, as well as the threat to public morality and the paternalistic idea of the protection of the good of the citizens. ${ }^{40}$ As for the limits of responsibility (exclusion), it is not possible to bring innocent persons to justice; it is permissible, however, to isolate persons as a socially ill (for a social treatment) and the consequences of being held accountable are usually proportional to the weight of the subject of responsibility. ${ }^{41}$ Despite the formal equality of every subject in violation of legal norms, the necessary defence, the state of higher necessity and other cases of excluded responsibility are accepted, according to parochial morality and the aims of punishment and social policy. ${ }^{42}$

Its philosophical foundation is compatibilism (reconciling the freedom of will with social regularities and the influence of the environment). It is a type implemented in the modernist period, between the 1950s and 1970s, especially in the USA, and also in the Scandinavian countries (in the era of paroxysm of the social rehabilitation model in penal law). The solutions established in those countries extended to other European legal systems. According to its assumptions, the system accepts a moderate thesis of anthropological determinism; therefore, the conditions of responsibility are largely objectified. ${ }^{43}$ Of course, there may be certain variants of each type. The liberal type is closer to the ideas of the welfare state and, therefore, responsibility is influenced by subjectivist tendencies. This type demonstrates a sufficient amount of characteristics to qualify as liberal. Responsibility in European countries has been shaped in a similar way, since more or less the 1970s and 1980s. Nowadays, however, it is difficult to ignore the opposite tendency, aiming at the objectivisation of the terms of responsibility, both in civil and in criminal law. When it comes to the socio-liberal type, it can take an extreme form, edging towards communitarian ideals. Such a type is characterised by a utilitarian justification of responsibility (consequentialism), which is included in social rehabilitation

\footnotetext{
37 cf. Sadurski (1988: 351-373), Dolinko (1991: 539-559).

38 See de Greiff (2002: 373-403), Kymlicka (1989: 206-219), Hampton (1994: 159-182).

39 Kaufman (1960: 49-53), Ten (1989: 7-37).

40 Christie (1977: 1-15).

41 cf. Dripps (1998: 3-18).

42 Fleurbaey (2008: 245-276).

43 Strawson (1962: 187-211), Frankfurt (1969), Fischer (1982: 24-40), Dennett (2003).
} 
activities. The terms of responsibility are formed in accordance to the principle of social harm (danger). The range and subject of responsibility are determined by the principle of damage (to a limited extent) and, primarily, the threat to public morals - the conditions of responsibility are, to a large extent, objectified. ${ }^{44}$

When it comes to the limits of responsibility (exclusion of responsibility), it is possible to hold the innocent liable and to isolate people in the curative (or other) mode. The effects of holding them accountable are not always proportional to the weight of the subject. The lack of equality in terms of the violation of legal norms is also characteristic. Generally, a necessary defence is accepted, as is a state of higher necessity etc., however, only if there are visible grounds for it in common morality. Using the word "extreme" may suggest that the circumstances under which responsibility is shaped, according to the socio-liberal type, should not be accepted. According to the persuasive, democratic mode, however, it exhibits a sufficient number of features to be considered as socio-liberal. What is more, this type is more likely to be characterised by the universality of curative and rehabilitation activities and the tendency to transfer the result from citizens to the community, which in this context is responsible for any deviant behaviour of its members. It also bears the responsibility for the socialisation of citizens. ${ }^{45}$

(c) Totalitarian type. This type of responsibility has features similar to the socio-liberal communitarian type. In a radical, totalitarian form, responsibility is entirely based on a differently understood threat to society and the state; an example of such responsibility is the communist law at the early stages of the Soviet Union or Nazi law, i.e. German law from the time of the Third Reich. ${ }^{46}$ This type is characterised by special rules of responsibility based on appointing judiciary institutions of very simplified procedural rules, limiting evidential proceedings to a minimum. Usually, there is no response to the allegation; however, there is a penalty related to an undesirable act or state, for example, class, race or nationality. The special modes usually functioned together with standard ones, with the division of imprecise competences among public authorities (just like in the General Governorship in occupied Poland in 1939-1945). In this sense, this type of responsibility was formed in a similar way to administrative responsibility. The rules were much simpler compared to classical criminal law, and the only important step was perpetration. ${ }^{47}$

(d) Quasi-democratic type. This is connected with three fundamental assumptions. The first concerns ideological background. Criminal law is a tool for introducing a specific doctrine of morality and vision of society. In Poland, this point of reference is the doctrine of the Catholic Church. Second, crimes are defined according to natural law, precluding a discourse to determine their content by interested citizens. Third, freedom is far less important as a value than collec-

\footnotetext{
44 Bayles (1974: 174-188).

45 Ancel (1965: 13), Garland (2001: 27-52), Peno (2016: 28-38), Andenaes (1957: 407-413).

46 Hiroven (2010: 117-147).

47 cf. Snyder (2016).
} 
tive property (for example, historical memory or national interest). At the same time, solutions largely excluding criminal responsibility (necessary defence) are also accepted, including the defence of the interests of others, rather than the interests of the victim of the attack. Punishment is treated essentially as a payoff, but recently we noticed a significant increase in its referential dimension. It is supposed to be aimed at particular groups of perpetrators (greater responsibility of public officials or officers, more severe responsibility of perpetrators of crimes against life, a zero tolerance policy for offenders of the most serious crimes, such as murder or those against national interests, but moderately mild treatment of sexual crimes, such as rape, abuse etc.). Another aspect concerns ignoring the interests of crime victims, for example, by reducing aid funds and the ways of their distribution. It also influences the shape of the criminal law system. ${ }^{48}$

There is definitely more to say about typologies. The approximation of the criminal law model to some of these types may be treated as a warning sign, while in others it may be a goal worth pursuing. Thus, they can be considered useful guidance for the legislator and citizens evaluating the state of de lege lata. ${ }^{49}$

\section{Conclusion}

It seems that when it comes to theoretical considerations on criminal law, it is worth using models to form particular legislative solutions. Such models may also be used in the formation of international criminal law, for instance, European criminal law. The concept of the principle of law is key. The term "principle" has three meanings. It can refer to a certain type of norms in criminal acts (so-called criminal responsibility principles addressed to citizens) or to directives addressed to the legislator themselves, taking the form of binding norms aimed at building a system of criminal responsibility, directive expediency or rules for the performance of conventional activities, especially law-making (criminal law). Considering the patterns of shaping the criminal law system (or criminal responsibility as the core of criminal law), it is possible to identify what connects principles to legal institutions. ${ }^{50}$ The complexity and multiplicity of theoretical considerations of criminal law are enormous. Systematising work on criminal law and its changes is worth pursuing. Systematisation and reformulation of the theory of punishment (as a meta-theory, or as the second level theory of punishment) may constitute a starting point for critique of the criminal law system as such. It is necessary to examine the rules (cultural, social, legal) that shape our thinking about criminal law. For this reason, it is necessary to answer the question: what are the patterns of criminal law and what are their sources. ${ }^{51}$ As previously emphasised, the ideas outlined in this article point out problems, not

\footnotetext{
48 cf. Skinner (2015: 35ff).

49 Duff (2010: 293-309), Jareborg (2004: 522-534).

50 Chiao (2016: 20-36).

51 Christie (1986: 1-18).
} 
solutions. It is worth emphasising the need not only of philosophical (axiological) reflection on criminal law but also of a theoretical one, related to building certain models of criminal law (e.g. in reference to the semiotic characteristics of norms or legal principles).

Funding The article was financed by the University of Szczecin (as part of its statutory activities).

\section{Compliance with Ethical Standards}

Human and Animal Rights Statement The study has non-empirical character.

Open Access This article is distributed under the terms of the Creative Commons Attribution 4.0 International License (http://creativecommons.org/licenses/by/4.0/), which permits unrestricted use, distribution, and reproduction in any medium, provided you give appropriate credit to the original author(s) and the source, provide a link to the Creative Commons license, and indicate if changes were made.

\section{References}

Alexy, Robert. 2000. On the Structure of Legal Principles. Ratio Juris 13 (3): 294-304.

Ancel, Marc. 1965. Social defence. A modern approach to criminal problems. London: Routledge and Paul Kegan.

Andenaes, Jos. 1957. Determinism and Criminal Law. Journal of Criminal Law, Criminology \& Police Science 406 (47): 407-413.

Anderson, Scott A. 2010. The Enforcement Approach to Coercion. Journal of Ethics and Social Philosophy 5 (1): 1-31.

Bayles, Michael. 1974. Criminal Paternalism. In The Limits of Law, ed. J.R. Roland Pennock and John W. Chapman, 174-188. New York: Lieber-Atherton.

Bennett, Christopher. 2002. The Varieties of Retributive Experience. Philosophical Quarterly 52 (207): $145-163$.

Bentham, Jeremy. 1817. A Table of the Springs of Action. London: R. Hunter.

Bilionis, Louis D. 1998. Process, The Constitution, and Substantive Criminal Law. Michigan Law Review 96 (5): 1269-1334.

Bobbio, Norberto. 1993. Thomas Hobbes and the Natural Law Tradition. Chicago: The University of Chicago Press.

Bohlander, Michael. 2009. Principles of German Criminal Law. Oxford, Portland, Oregon: Hart Publishing.

Branstetter, John. 2017. The Leviathan's Conscience: Hobbesian Human Nature and Moral Judgment. Political Research Quarterly 70 (4): 778-789.

Cane, Peter. 2002. Responsibility in Law and Morality. Oxford, Portland: Hart Publishing.

Carvalho, Hamilton. 2017. Liberty and Insecurity in the Criminal Law: Lessons from Thomas Hobbes. Criminal Law and Philosophy X (11): 249-271.

Chiao, Vincent. 2016. Two Conceptions of the Criminal Law. In The New Philosophy of Criminal Law, ed. Chad Flanders and Zachary Hoskins, 20-36. Lanham: Rowman and Littlefield.

Christie, Nils. 1986. Crime Control as Drama. Journal of Law and Society 13 (1): 1-18.

Christie, Nils. 1977. Conflicts as Property. British Journal of Criminology 17 (1): 1-15.

Cragg, Wesley. 2016. The Practice of Punishment: Towards a Theory of Restorative Justice. London, New York: Routledge.

Czepita, Stanisław. 1994. "Reguły konstrukcji systemu prawnego a prawotwórstwo". ["Rules of Construction of a Legal System and the Law-Making Process".]. Ruch Prawniczy, Ekonomiczny i Socjologiczny LVI (4): 31-38. 
de Greiff, P. 2002. Deliberative Democracy and Punishment. Buffalo Criminal Law Review 5 (2): 373-403.

Dennett, Daniel. 2003. Freedom Evolves. London: Penguin Books.

Dolinko, David. 1991. Some Thoughts about Retributivism. Ethics 101 (3): 537-559.

Dripps, D.A. 1998. The Liberal Critique of the Harm Principle. Criminal Justice Ethics 17: 3-18.

Dubber, Markus Dirk. 2004. Toward a Constitutional Law of Crime and Punishment. Hastings Law Journal 55 (3): 509-572.

Dubber, Markus Dirk. 2005. The Promise of German Criminal Law: A Science of Crime and Punishment. German Law Journal 1049 (6): 1-38.

Duff, Robin Antony. 2007. Answering for Answering for Crime. Responsibility and Responsibility in the Criminal Law. Oxford, Portland: Hart Publishing.

Duff, Antony. 2010. Criminal Law for Citizens. Theoretical Criminology 14: 293-309.

Dworkin, Robert. 1969. The Model of Rules. In Law, Reason, and Justice, ed. Graham Hughes, 14-29. New-York, London: University of London Press.

Dworkin, Robert. 1980. Taking Right Seriously. Harvard, Cambridge: Harvard University Press.

Feinberg, Joel. 1970. The Expressive Function of Punishment. Princeton: Princeton University Press.

Feteris, Eveline T. 1999. Fundamentals of Legal Argumentation. A Survey of Theories on the Justification of Judicial Decisions. Dordrecht: Springer.

Fischer, John Martin. 1982. Responsibility and Control. Journal of Philosophy 79: 24-40.

Fleurbaey, M. 2008. Fairness, Responsibility, and Welfare. Oxford: Oxford University Press.

Frankfurt, Harry. 1969. Alternate Possibilities and Moral Responsibility. Journal of Philosophy 66: 829-839.

Fuller, Lon. 1969. The Morality of Law, Revised ed. New Haven: Yale University Press.

Gainer, Ronald. 1998. Federal Criminal Code Reform: Past and Future. Buffalo Criminal Law Review 45 (2): 53-74.

Garland, David. 2001. The Culture of Control. Crime and Social Order in Contemporary Society. Chicago: The University of Chicago Press.

Habermas, Jurgen. 1987. The Theory of Communicative Action, Volume 2, System and Lifeworld: A Critique of Functionalist Reason. Boston, MA: Beacon Press.

Hampton, Jean. 1994. Liberalism, Retribution and Criminality. In In Harm's Way: Essays in Honor of Joel Feinberg, ed. Jules L. Coleman and Alan Buchanan, 159-182. New York: Cambridge University Press.

Harsanyi, John. 1982. Morality and the Theory of Rational Behaviour. In Utilitarianism and Beyond, ed. Amartya K. Sen and Bernard Williams, 39-62. Cambridge: Cambridge University Press.

Hiroven, Ari. 2010. Total Evil: The Law Under Totalitarianism. In Law and Evil. Philosophy, Politics, Psychoanalysis, ed. Ari Hirvonen and Janne Porttikivi, 117-147. New York: Routledge.

Honderich, Ted. 2005. Punishment The Supposed Justifications Revisited. London: Pluto Press.

Husak, Douglas. 2008. Overcriminalization. The Limits of the Criminal Law. New York: Oxford University Press.

Jareborg, Nils. 2004. Criminalization as Last Resort (Ultima Ratio). Ohio State Journal of Criminal Law 2: 522-534.

Johnson, O.A. 1969. Rightness and Goodness. A Study in Contemporary Ethical Theory. Hague: The Martinus Nijhoff.

Kaufman, Arnold. 1960. The Reform Theory of Punishment. Ethics 71 (1): 49-53.

Kymlicka, Will. 1989. Liberalian. Community and Culture. Oxford: Oxford University Press.

Kymlicka, Will. 2001. Contemporary Political Philosophy: An Introduction. Oxford: Oxford University Press.

Los, Maria W. 1988. Communist Ideology, Law and Crime. A Comparative View of the USSR and Poland. London: Palgrave Macmillan.

Lucas, John Randolph. 2004. Responsibility. Oxford: Oxford University Press.

Merryman, John Henry. 1969. The Civil Law Tradition. An Introduction to the Legal Systems of Western Europe and Latin America. Stanford: Stanford University Press.

Nowak, Leszek. 1987. A Concept of Rational Legislator. In Polish Contributions to the Theory and Philosophy of Law. Series: Poznan Studies in the Philosophy of the Sciences and the Humanities, ed. Zygmunt Ziembiński, 137-147. Amsterdam: Brill Rodopi.

Nozick, Robert. 1981. Philosophical Explanations. Cambridge, MA: Harvard University Press.

Peczenik, Aleksander. 2005. Scientia Juris: Legal Doctrine as Knowledge of Law and as a Source of Law. Dordrecht: Springer. 
Peno, Michał. 2016. Punishing (Non-)Citizens. Archives for Philosophy of Law and Social Philosophy 2 (13): 28-38. (Polish edition).

Peno, Michal, and Jacek Jaśkiewicz. 2018. Rule of Law as the Construction Principle of the Legal System. In Rule of Law at the Beginning of the Twenty-First Century, ed. Martin Belov, 21-33. Hague: Eleven International Publishing.

Pereboom, Derk. 2003. Living Without Free Will. New York: Cambridge University Press.

Primoratz, Igor. 1989. Punishment as Language. Philosophy 64 (248): 187-205.

Ripstein, Arthur. 1999. Equality, Responsibility and the Law. New York: Cambridge University Press.

Ristroph, Alice. 2016. Two Conditions of Legitimate Punishment. In The New Philosophy of Criminal Law, ed. Chad Flanders and Zachary Hoskins, 76-92. New York: Rowman and Littlefield.

Ross, Alf. 1968. Directives and Norms. London: Routledge \& Kegan Paul Ltd.

Ryberg, Jasper. 2004. The Ethics of Proportionate Punishment. A Critical Investigation. Dordrecht: Kluwer Academic Publishers.

Sadurski, Wojciech. 1988. Theory of Punishment, Social Justice, and Liberal Neutrality. Law and Philosophy 7 (3): 351-373.

Scalia, Antonin. 1989. The Rule of Law as a Law of Rules. University of Chicago Law Review 56 (4): 1175-1188.

Selznick, Philipp. 1994. Moral Commonwealth: Social Theory and the Promise of Community. Berkeley: University of California Press.

Shapiro, Ian. 2003. Moral Foundations of Politics. New Haven: Yale University Press.

Skinner, Stephen. 2015. Fascism and Criminal Law: History, Theory, Continuity. Oxford, Portland, Oregon: Hart Publishing.

Snyder, Timothy. 2016. Black Earth: The Holocaust as History and Warning. New York: Tim Duggan Books.

Starosolsky, George V. 1950. Principles of Soviet Criminal Law. North Carolina Law Review 28 (4): 359-374.

Strawson, Peter F. 1962. Freedom and Resentment. Proceedings of the British Academy 48: 187-211.

Tebbit, Mark. 2005. Philosophy of Law. London, New York: Routledge.

Ten, Chin Liew. 1989. Crime, Guilt, and Punishment. Oxford: Clarendon Press.

Tunick, Mark. 1992. Punishment. Theory and Practice. Berkeley, Los Angeles, Oxford: University of California Press.

Vilhauer, Benjamin. 2013. Persons, Punishment, and Free Will Skepticism. Philosophical Studies 162 (2): $143-163$.

von Wright, Georg Henrik. 1963. Norm and Action. A Logical Enquiry. London: Routledge \& Kegan Paul.

von Wright, Georg Henrik. 1985. Is and Ought. In Man, Law, and Modern Forms of Life, ed. Eugenio Bulygin, Jean-Louis Gardies, and Ilkka Niiniluoto, 6-17. Dordrecht: Reidel.

Woleński, Jan, ed. 1999a. The Problem of "Directive Meaning". In Kazimierz Opałek Selected Papers in Legal Philosophy, 201-215. Dordrecht: Springer.

Woleński, Jan, ed. 1999b. Some Problems of the Theory of Norms. In Kazimierz Opałek Selected Papers in Legal Philosophy, 201-215. Dordrecht: Springer.

Wronkowska, Sławomira, Maciej Zieliński, and Zygmunt Ziembiński. 1987. The Methodological Problems Concerning The Principles of Law. In Polish Contributions to the Theory and Philosophy of Law. Series: Poznań Studies in arlandthe Philosophy of the Sciences and the Humanities, ed. Zygmunt Ziembiński, 179-188. Amsterdam: Brill Rodopi.

Zaibert, Leo. 2006. Punishment and Revenge. Law and Philosophy 25 (1): 81-118.

Publisher's Note Springer Nature remains neutral with regard to jurisdictional claims in published maps and institutional affiliations. 